\title{
Assisted migration vs. close-to-nature forestry: what are the prospects for tree populations under climate change?
}

\author{
Dušan Gömöry ${ }^{1 *}$, Diana Krajmerová ${ }^{1}$, Matúš Hrivnák ${ }^{1}$, Roman Longauer ${ }^{2,3}$ \\ ${ }^{1}$ Technical University in Zvolen, Faculty of Forestry, T. G Masaryka 24, SK- 96001 Zvolen, Slovak Republic \\ ${ }^{2}$ National Forest Centre, T. G. Masaryka 2175/22, SK - 96001 Zvolen, Slovak Republic \\ ${ }^{3}$ Mendel University in Brno, Faculty of Forestry and Wood Technology, Zemědělská 2, CZ - 61300 Brno, Czech Republic
}

\begin{abstract}
Climate change is currently perceived as the most important challenge faced globally by ecosystems and human society. The predicted changes of temperature and precipitation patterns are expected to alter the environmental conditions to which forest trees in Europe are adapted, and expose them to new pests and pathogens. This would unavoidably lead to a huge loss of ecosystem services provided to society, and at the local scale may potentially endanger the very existence of forests. In this study, we reviewed biological background and limits of mechanisms by which tree populations may cope with climate change: adaptation by natural selection, gene flow, epigenetic phenomena and phenotypic plasticity, as well as forest management strategies, which rely on these mechanisms. We argue that maintaining genetic diversity is important in the long-term view but natural selection cannot ensure sufficiently rapid response to environmental change. On the other hand, epigenetic memory effects may change adaptively relevant traits within a single generation, while close-to-nature forestry practices are the basic requirement to make use of epigenetics. Assisted migration, as a frequently suggested mitigation option, relies primarily on the knowledge gained from provenance research; the review analyses potential pitfalls of this strategy. We suggest that all approaches, i.e., leaving a part of forests without management, close-to-nature forestry, and transfer of forest reproductive materials from sources presumably adapted to future climates are combined across the landscape in an integrative manner.
\end{abstract}

Key words: adaptation; epigenetics; phenotypic plasticity; provenance; climate change mitigation

Editor: Zdeněk Vacek

\section{Introduction}

Under rapidly changing environments, living organisms can choose between two strategies to survive: migration into more suitable habitats, and local persistence through adaptation (Aitken et al. 2008). The third option (if it is to be considered an option) is extinction. These potential strategies apply to tree populations as well, and the ongoing climate change makes them highly up-to-date, as the scenarios of climate development display sometimes a very dramatic picture of future environments (IPCC 2014; Ripple et al. 2019). Moreover, trees represent edificators of forest ecosystems; the future of tree populations determines the fate of a broad spectrum of forest-dwelling organisms.

Forestry practice largely mimics processes going on in natural forest ecosystems. Consequently, from the point of view of a forester, the choice of strategies in the face of climate change is in fact identical: the forester can rely on natural capacities of tree species to cope with warm- ing and drying climate and try to enhance them through sylvicultural interventions in forest stands, or try to influence genetic composition of forest stands by the choice of forest reproductive materials (FRM) for reforestation (Konnert et al. 2015). Both strategies are currently intensively discussed. The former requires utilization of natural ecological and microevolutionary processes as applied in close-to-nature (or continuous-cover) forestry, which learns from the dynamics of natural old-growth forests (ProSilva 2012; Schütz et al. 2016). This concept is, however, not free of controversies: on one hand, it has become the main management approach in several countries such as Slovenia or Switzerland (Schütz et al. 2016), on the other hand, it was labelled as a non-concept and doubts were expressed about its applicability (O'Hara 2016). The same applies to large-scale FRM transfers: although being most often suggested by expert community as a remedy against climate change, their perception by general public is not always positive (St-Laurent et al.

*Corresponding author. Dušan Gömöry, e-mail: gomory@tuzvo.sk 
2018), and their associated risks and uncertainties are mentioned (Montwe et al. 2018; Silvestro et al. 2019).

Whatever is the personal preference of a particular forester, recent development of forest condition in Central Europe clearly demonstrated that continuing business-as-usual unavoidable results in large-scale destruction of forests, especially (but not solely) even-aged monospecific stands of conifers. In this opinion paper we review risks and prospects of both above-mentioned strategies under the view of heritable variation (genetic or epigenetic) and its use in the mitigation of climate change effects on forest ecosystems.

\section{Capacity of natural populations to cope with climate change and its limits}

There are several features of forest trees as a group that favour their persistence in changing environments: mostly large population sizes, high fecundity, plasticity and generally spatially extensive dispersal (Aitken et al. 2008; Anderson 2016). Only generation turnover, typically very long compared to most herbs, is a disadvantageous characteristic in this context.

In natural ecosystems without human influence, populations have used two strategies to persist in their habitats. In long term, organisms adapt to environmental variation (both spatial and temporal) through natural selection. At a short temporal scale, they respond to environmental fluctuation through phenotypic plasticity. However, nature does not know time constraints. In contrast, a forester needs to take into account not only the time scale at which both these strategies operate, but also needs to consider practical issues such as their costs in terms of the loss of forest functions, which is at stake. Maintaining broad genetic variation in order to preserve the potential for evolutionary adaptation by natural selection is a strategy requiring timeframes of many generations to be effective, which in case of trees means centuries, maybe millennia. Even if the gene targeted by selection is dominant, the between-generation change of allele frequencies is small unless selection is extremely strong (Falconer \& Mackay 1996). Moreover, selection may be hindered by trade-offs between fitness-related traits (Sthultz et al. 2009; Darychuk et al. 2012), which are typically polygenic (Jermstad et al. 2001), meaning that trade-offs among loci, epistatic interactions etc. further complicate the evolutionary response to such a complex selection pressure as climate change.

Gene flow is another mechanism which makes predictions about buffering capacity of natural populations against climate change uncertain. Marker studies based on paternity analysis or model approaches (e.g., TwoGener; Smouse 2001) yielded mean dispersal distances around tens or hundreds of meters (for overview, see Savolainen et al. 2007). However, the distribution of dispersal distances is highly skewed with a significant right tail; empirical assessment of pollen flow showed that in anemophilous species such as pines, pollen can be transferred viable over hundreds of kilometres (Lindgren et al. 1995; Kremer et al. 2012). Reproductive success of such pollen is probably not big because of differences in flowering phenology and competition with local pollen; therefore, genes are mostly transferred in a steppingstone manner, resulting in large-scale clines of gene frequencies and the resulting phenotypic traits produced by isolation by distance (Gömöry et al. 2012a; Bošela et al. 2016). The same applies to pollen flow among altitudinal belts in the mountains: physical distance is mostly not a problem for pollen flow but differences in timing of flowering associated with altitudinal gradients of temperatures constrain direct gene exchange between populations at contrasting elevations (Brunet et al. 2012; Holliday et al. 2016). The effect of gene flow on average fitness of local populations, irrespective of its extent, is difficult to assess. In the case of strong local adaptation, the effect is expected to be detrimental: incoming genes may be maladaptive, and in the offspring generation breakdown of co-adapted gene complexes may occur (Charlesworth \& Willis 2009; Lindtke et al. 2012). On the other hand, under unstable environments, gene flow may bring in useful genetic variants available in the species' gene pool but absent in a local population. However, the net effect is unknown and there is virtually no experimental evidence on this issue.

In spite of this, forest trees have used the strategy of adaptation by selection to cope with environmental change in their history, as evidenced by the existence of local races, ecotypes, and more generally, by intraspecific adaptive genetic variation documented in provenance trials. On the other hand, provenance trials have also documented another typical feature of tree populations, namely the adaptation lag (Mátyás 1996): adaptational optimum is seldom attained in natural populations, which shows the limits of this strategy.

Phenotypic plasticity, the alternative strategy, is a vital feature of forest trees as long-lived organisms, allowing them to cope with environmental fluctuations during their long life span. Phenotypic plasticity can be defined as the capacity of a given genotype to render different phenotypes under different environmental conditions (Valladares et al.2006). This implies that the organism is capable to modify its developmental pathway in response to environmental stimuli. There is a wide variety of cellular and molecular mechanisms, which may potentially be responsible for the ability of a given set of genes to produce different phenotypes under different environments, including differential transcription or translation levels, allosteric switches and post-translational modifications of proteins, metabolic control, changes of signaling pathways etc. (Schlichting \& Smith 2002; Nicotra et al. 2010). A part of these mechanisms is associated with chemical modification of the hereditary material (the DNA itself or protein constituents of the chromatin 
- histones) or with transposon activation, expansion of short repeats etc. - all these mechanisms do not change the sense of the information contained in genes but affect the expression level of a particular gene or genes. Some of these modifications are transferred to daughter molecules during the DNA replication and, consequently, appear in the 'hereditary outfit' of the offspring: either they are associated with the change of the DNA sequence (e.g., transposon-associated changes) and hence should be classified as genetic, or they represent just chemical changes (cytosine methylation) and then constitute the basis of epigenetic inheritance.

Naturally, this definition of phenotypic plasticity leaves considerable flexibility in deciding what processes and phenomena the term comprises, both in terms of the size of phenotypic effect and the persistence of this effect during the ontogeny of an organism. A more stringent concept restricts phenotypic plasticity to developmental processes when developmental pathway is largely irreversibly set in early ontogenetic stages and ultimately results in a stable phenotype. A looser view includes any environment-induced phenotypic expression changing after the environmental stimulus disappears, or even gene regulatory processes that may have no gross phenotypic effects (DeWitt \& Scheiner 2004). Whatever concept a practical forester adopts, the crucial issue is how broad the reaction norm of tree populations is. Whether the reaction of a tree species to changed environment is associated with a visible modification of the phenotype is not as important as the ability to survive and reproduce under new conditions.

While the above strategies were associated with the persistence in current habitats, tree populations may also migrate when their current sites become no more suitable for survival. Signs of such range shifts can already be observed (Woodall et al. 2009). Migration rates are the most important factor for the success of this strategy. Unfortunately, our knowledge of migration rates largely relies on the Holocene colonization, while it is not fully clear whether the speed of the Holocene spread of trees was governed primarily by the speed of Holocene warming or the dispersal capacity of trees (cf. Huntley et al. 1995). Nevertheless, the disparity between the observed migration rates and the rate of displacement of tree habitats under the ongoing climate change is considerable. Feurdean et al. (2013) estimated maximum migration rates for early-successional species such as birch or Scots pine to 225-540 $\mathrm{m} \mathrm{yr}^{-1}$, while for climax trees such as silver fir or beech they range between 115 and $385 \mathrm{~m} \mathrm{yr}^{-1}$ (of course, depending also on the mode of dispersal, animal or wind). In fact, in a fragmented landscape and under a strong ungulate pressure the recent colonization rates may even be considerably smaller. In contrast, even moderate climate change scenarios predict latitudinal (i.e. horizontal) shift of the isotherm by $3 \mathrm{~km} \mathrm{yr}^{-1}$ (Mátyás 2007); obviously, tree migration cannot keep pace with the speed of habitat changes. Moreover, postglacial colo- nization occurred in non-disturbed landscapes. Range fragmentation typical for most of Europe substantially reduces the migration speed, as both the size of source populations producing propagules and availability of target sites colonized by these propagules are reduced (Iverson et al. 2004). In mountainous countries such as Slovakia, evasion into higher elevations may be an additional option. However, the speed of the vertical shift of the isotherm (estimated at $11.5 \mathrm{~m} \mathrm{yr}^{-1}$; cf. Mátyás 2007) may be prohibitive for altitudinal migration for several tree species as well.

\section{What are the options for forestry practice?}

Although maintaining broad genetic variation in tree populations remains an important task for practical forestry, migration to new sites or selection of appropriate genetic variants seem to be too slow processes to allow adaptation to rapid climate change in organisms having as long generation turnover as trees. In contrast, heritable phenotypic change through chemical modification of the hereditary material resulting in changed gene expression patterns can appear very rapidly. Vegetative phenology is a good example of an important adaptive trait whose control may be at least partly epigenetic. In European beech (Fagus sylvatica), phenological responses to climate reflect local adaptation but at the same time, significant genotype-by-environment interactions indicate that they are phenotypically plastic (Kramer et al. 2017). In conifers, timing of spring flushing and autumn growth cessation, and consequently frost hardiness are largely determined by day length and temperature during seed development (Skrøppa 1994; Johnsen et al. 2005). Epigenetic carryover effect may cause changes of phenology from the parental generation to the offspring even for provenances transferred over several degrees of latitude: in Norway, budset dates of the offspring of Norway spruce (Picea abies) introduced from Germany and Austria a century ago were shown to resemble more the local Norwegian families than families newly imported from Central Europe (Skrøppa et al. 2009). Such newlyacquired expression pattern may remain stable for further generations (genetic assimilation; cf. Pigliucci et al. 2006). A similar effect may be induced by the climate of the site of juvenile development (Gömöry et al. 2015). In terms of climate change, such behaviour is promising, as it means that physiological adaptation does not necessarily require genetic change, and generation turnover makes the population fit to the changed climate. On the other hand, epigenetic memory was proved in forest trees only in association with phenology and frost resistance; its importance related to growth, drought tolerance and other climate-relevant traits has not been explicitly confirmed. Observations in provenance experiments, where identical provenances are planted on climatically 
contrasting sites, indicate that phenotypic plasticity in drought-related traits such as resistance to xylem embolism is extensive and induced by the local climate (Wortemann et al. 2011); this is not a proof but still an indication for a potential role of epigenetics in drought resistance. The use of the epigenetic memory to make the future tree generation accommodated to new climate requires, however, that both reproduction and juvenile growth must occur at the site where the new climate appears, under as natural conditions as possible. This implies that the developing seeds and seedlings do not leave the site even temporarily, so it is not practically feasible with reforestation. Even when the offspring is planted back in the forest stand where the seeds were collected, the nursery for raising the plants is always placed elsewhere. Of course, leaving the reproduction completely to natural processes (as it is done in nature reserves or other types of wilderness) is an option, but not for commercial or managed forests, where timber production is one of the expected benefits. Active sylvicultural management does not contradict natural regeneration; nevertheless, not all sylvicultural systems are equally suitable in terms of potential epigenetic effects. Approaches resulting in synchronized natural regeneration on large plots such as uniform shelterwood system or strip fellings performed on broad strips lead to quite unnatural environments for developing seedlings just during juvenile stages of ontogeny (Matthews 1989; Puettmann et al. 2009). Of course, macroclimate fits even in this case; the question is to what extent microclimate of a large open area may differ from that of a closed stands and thus adversely affect the offspring generation.

In addition to epigenetics, sylviculture also affects genetics: sylvicultural measures may enhance as well as hamper evolutionary processes such as gene flow and natural selection by affecting simultaneously species demography and local environmental conditions (Finkeldey \& Ziehe 2004). Even though a sufficiently rapid adaptation to climate change through natural selection of appropriate genetic variants is not realistic, maintaining or increasing genetic diversity as a basis for the stability of tree populations in response to environmental fluctuations remains important goal of sylvicultural management in a long-term view (Lefèvre et al. 2014).

Assisted migration is another option to accommodate forest tree populations to changed climate, currently broadly advocated by many forest geneticists and breeders (Mátyás 1994; Aitken \& Whitlock 2013; Williams \& Dumroese 2013; Konnert et al. 2015; Aitken \& Bemmels 2016). Assisted migration includes assisted gene flow, i.e., intentional translocation of individuals (in any stage of ontogeny) within the natural range of a species, and assisted colonization, i.e., translocation of individuals outside the range, which implies a change of species composition of forest stands at the target site (Aitken \& Whitlock 2013). Both approaches involve the transfer of FRM (in the case of assisted gene flow also movement of pollen can be considered, but is rarely practiced except in the form of supplemental pollination in seed orchards). While assisted gene flow relies on non-local provenances of native tree species, assisted colonization also includes the use of non-native tree species.

The choice of appropriate provenances is a crucial aspect of the FRM-transfer strategy. In spite of a rapid development in the field forest genomics during the last two decades (Neale \& Kremer 2011; Plomion et al. 2016), the application of the results of genomic studies in setting the FRM transfer rules is still associated with many caveats (cf. Lind et al. 2018). Until physiological mechanisms underlying phenotypic traits relevant in the climate-change context are known and their controlling genes are identified (while genetic dissection of phenotypic traits in general is still in a very initial phase), practical applicability of genomics is very limited. In practice, the current reflections about provenance choice under climate change are based on climate matching: the search for provenances growing currently in climates, which are expected to occur at the reforestation site in the future. The climate envelope approach, traditionally applied in assessment of species climate sensitivity (Bolte et al. 2009) can in principle be applied also at the population level.

Consequently, the most reliable information source for guiding assisted migration constitute commongarden experiments, where the performance of different populations under particular climates is explicitly tested. The importance of provenance trials for guiding the FRM transfer was recognized early (Mátyás 1994). Provenance recommendations have sometimes been based on anecdotal experience with the performance of particular provenances in simple small-scale trials. However, nowadays range-wide experiments comprising tens of provenances replicated across several climatically diverse test sites are available for most commercially or ecologically important tree species. Such trials can be used in two ways. A specific way is determining the environment where a particular provenance performs best or choosing the optimum provenance for a particular site. A conceptually broader way is the identification of patterns of climate-related responses, which allows setting generalized rules for provenance transfer. Two primary approaches have been developed for this purpose: general transfer functions and population response functions (Rehfeldt et al. 1999; Aitken et al. 2008). From the point of view of methodology, both approaches relate some fitness-related trait (typically survival, height growth or biomass production) of the translocated population to translocation rate, i.e., the climatic (or geographic) distance between the site of origin and the site of plantation ('ecological distance' or 'ecodistance'; cf. Mátyás 1994), and look for the climatic optimum, i.e. the rate of transfer at which the whole provenance set often combined across different experiments (general transfer function) or a particular provenance (population response func- 
tion) performs best. These approaches allow provenance recommendations also under climate change, provided a reliable climate prediction for a particular planting site is available.

Even though the advantages of common-garden experiments for the assessment of future behavior of tree populations under climate change are obvious, there are still several problematic aspects of this approach (see Konnert et al. 2015). One is associated with the methodology of provenance research. There are no universal guidelines for the collection of seedlots representing provenances, which implies that the material used does not necessarily properly represent the genetic setup of the maternal stand (too few maternal trees, unbalanced family sizes, seed collection during a poor-crop year). Further, plants are typically raised together in a nursery. Optimized microclimatic and soil conditions as well as other nursery practices reduce the playground for natural selection, and cause epigenetic imprinting (Gömöry et al. 2015) which may influence the performance of provenances during later ontogenetic stages. The same applies to outplanting: typically, wide spacing, weed control and fencing against deer are used, which all may distort the assessment of survival rates as an important fitness measure. The selection of provenances and planting sites is not necessarily random: often provenances performing well in older trials or conspicuous by other relevant properties are systematically offered into international experiments (e.g., Polish well-growing Norway spruce provenance Istebna or Slovenian late-flushing beech provenance Idrija), and ecologically marginal planting sites are avoided. Another set of problems is associated with the measurement of trials. Most studies are based on trial assessments at juvenile age. The measurements of height growth as an 'obligatory' parameter gradually become technically complicated with increasing age, not to mention physiological traits such as gas exchange or photosynthesis. Studies at the age of $40+$ years exist but are rare (e.g., Gömöry et al. 2012b); however, even in this case it remains questionable whether they can be extrapolated to the age of stand rotation. Finally, modelling of tree-climate relationship requires relevant and reliably assessed climatic characteristics of both plantation sites and sites of origin. Currently, climate variables at fine resolution can easily be acquired from public sources such as WorldClim, ClimateEU or EuroCordex (Fick and Hijmans 2017; http://tinyurl.com/ClimateEU; https:// www.euro-cordex.net/). Nevertheless, as interpolated data they are by principle loaded by a certain error. There is also a certain dilemma about the choice of appropriate climate proxies: on one hand, general climatic variables such as mean annual temperatures or annual precipitation totals may poorly reflect actual driving forces of climatic adaptation; on the other hand, more sophisticated climatic indices may be difficult to be calculated and applied in practice except in computer-based decision-support systems. Moreover, provenance choice for assisted migration requires a reliable prediction of future climates. Even if there was a general consensus on mathematical modeling of the development of climate, a realistic climatic scenario would require knowledge about greenhouse gas emissions, which depends on future decisions of the human society.

In any case, obligatory permanent keeping records of the origin of any FRM used for reforestation is a basic prerequisite of further assessment of the effectiveness of assisted migration. The current practice of abandoning records after the expiration of forest management plans does not allow evaluation of experience with the performance of the artificially established forest stands.

\section{Conclusion}

As explained above, all strategies of mitigation of climate change effects are loaded by uncertainties and risks of their own. In such a situation risk diversification is the only reasonable solution. Economic theory advises not to keep all assets in the same pocket. Biology should advise to do the same, and combine all approaches (Messier et al. 2019). First, 'mother nature' should be left to do its job in a part of forests, i.e., a reasonably large part of forests needs to be strictly excluded from any active management; mainly to leave space for natural forces to act, but also to preserve a possibility to learn from natural processes. Of course, what is 'reasonably large part' may be a matter of discussion; for sure it should comprise all current forest reserves and all existing old-growth fragments, even when they are not yet under legal protection, and a part of managed forests in large-scale protected areas such as national parks can also be converted into wilderness. Second, sylvicultural treatments should vary across the landscape to create alternating areas of structurally diverse forest stands with long regeneration periods, differentiated by age, and areas with shorter rotation periods with lower disturbance risks and allowing for faster species turnover (Brang et al. 2014; Spathelf et al.2015). Spatially varying cutting regimes contribute to the formation of variable ecological niches and impose variable selective pressures on trees; consequently, foster genetic diversity (Fady et al. 2016). Naturally, practical application must conform to the condition of each particular forest stand. Continuous cover forestry cannot be applied everywhere, but for sure it can be applied at much larger scale than currently. Third, the knowledge gained from translocation experiments must be applied in forestry practice in spite of all uncertainties, which means transfer of FRM from warmer and drier regions. In a mountainous country such as Slovakia this may not necessarily mean import of FRM but also altitudinal transfer. In any case, assisted migration should primarily focus on transfer of provenances of native species rather than introduction of non-native species. Again, risk reduction implies the use of multiple provenances 
and species (Konnert et al. 2015). Forestry legislation needs to be adapted to allow these measures. In Slovakia, the first step was accomplished by adopting a new Forest Code no. 355/2019, which introduced the concept of close-to-nature forestry. Now, it is time to amend the legislation on forest reproductive material, in Slovakia as well as elsewhere in Central Europe, to allow FRM transfer on larger scales.

\section{Acknowledgements}

This study was supported by research grants of the Slovak Research and Development Agency no APVV-16-0306 (DG, DK), Slovak Grant Agency for Science VEGA 1/0029/20 (MH, $D G)$, and the project Centre of excellence of forestry and woodprocessing complex LignoSilva (ITMS code: 313011 S735) of the Operation Programme Integrated Infrastructure 2014-2020, co-financed from the European Regional Development Fund (RL).

\section{References}

Aitken, S. N., Yeaman, S. , Holliday, J. A., Wang, T., Curtis-McLane, S., 2008: Adaptation, migration or extirpation: climate change outcomes for tree populations. Evolutionary Applications, 1:95-111.

Aitken, S. N., Whitlock, M. C., 2013: Assisted gene flow to facilitate local adaptation to climate change. Annual Review of Ecology, Evolution and Systematics, 44:367-388.

Aitken, S. N., Bemmels, J. B., 2016: Time to get moving: assisted gene flow of forest trees. Evolutionary Applications, 9:271-90.

Anderson, J. T., 2016: Plant fitness in a rapidly changing world. New Phytologist, 210:81-87.

Bolte, A., Ammer, C., Löf, M., Madsen, P., Nabuurs, G. J., Schall, P. et al., 2009: Adaptive forest management in central Europe: climate change impacts, strategies and integrative concept. Scandinavian Journal of Forest Research, 24:473-482.

Bošela, M., Popa, I., Gömöry, D., Longauer, R., Tobin, B., Kyncl, J. et al., 2016: Effects of post-glacial phylogeny and genetic diversity on the growth variability and climate sensitivity of European silver fir. Journal of Ecology, 104:716-724.

Brang, P., Spathelf, P., Larsen, J. B., Bauhus, J., Bončina, A., Chauvin, C. et al., 2014. Suitability of close-tonature silviculture for adapting temperate European forests to climate change. Forestry, 87:492-503.

Brunet, J., Larson-Rabin, Z., Stewart, C. M., 2012: The distribution of genetic diversity within and among populations of the Rocky Mountain columbine: the impact of gene flow, pollinators, and mating system. International Journal of Plant Sciences, 173:484-494.

Charlesworth, D., Willis, J. H., 2009: The genetics of inbreeding depression. Nature Reviews Genetics, 10:783-796.
Darychuk, N., Hawkins, B. J., Stoehr, M., 2012: Tradeoffs between growth and cold and drought hardiness in submaritime Douglas-fir. Canadian Journal of Forest Research, 42:1530-1541

DeWitt, T. J., Scheiner, S. M., 2004: Phenotypic variation from single genotypes: a primer. In: DeWitt, T. J., Scheiner, S. M. (eds.): Phenotypic plasticity functional and conceptual approaches. New York, Oxford University Press, p. 1-9.

Fady, B., Cottrell, J., Ackzell, L., Alía, R., Muys, B., Prada, A. et al., 2016: Forests and global change: what can genetics contribute to the major forest management and policy challenges of the twenty-first century? Regional Environmental Change, 16:927-939.

Falconer, D. S., Mackay, T. F. C., 1996: Introduction to Quantitative Genetics. Harlow, Longman Press, $480 \mathrm{p}$.

Feurdean, A., Bhagwat, S. A., Willis, K. J., Birks, H. J. B., Lischke, H., Hickler, T., 2013: Tree migration-rates: narrowing the gap between inferred post-glacial rates and projected rates. PLoS ONE, 8:e71797.

Fick, S. E., Hijmans, R. J., 2017: Worldclim 2: New 1-km spatial resolution climate surfaces for global land areas. International Journal of Climatology, 37:4302-4315.

Finkeldey, R., Ziehe, M., 2004: Genetic implications of silvicultural regimes. Forest Ecology and Management, 197:231-244.

Gömöry, D., Foffová, E., Longauer, R., Krajmerová, D., 2015: Memory effects associated with the earlygrowth environment in Norway spruce and European larch. European Journal of Forest Research, 134:89-97.

Gömöry, D., Longauer, R., Hlásny, T., Pacalaj, M., Strmeň, S., Krajmerová, D., 2012b: Adaptation to common optimum in different populations of Norway spruce (Picea abies Karst.). European Journal of Forest Research, 131:401-411.

Gömöry, D., Paule, L., Krajmerová, D., Romšáková, I., Longauer, R., 2012a: Admixture of genetic lineages of different glacial origin: a case study of Abies alba Mill. in the Carpathians. Plant Systematics and Evolution, 298:703-712.

Holliday, J. A., Zhou, L. C., Bawa, R., Zhang, M., Oubida, R. W., 2016: Evidence for extensive parallelism but divergent genomic architecture of adaptation along altitudinal and latitudinal gradients in Populus trichocarpa. New Phytologist, 209:1240-1251.

Huntley, B., Berry, P., Cramer, W., McDonald, A. P., 1995: Modelling present and potential future ranges of some European higher plants using climate response surfaces. Journal of Biogeography, 22:967-1001.

IPCC, 2014: Climate Change 2014: Synthesis Report. In: Pachauri, R. K., Meyer, L. A. (eds.): Contribution of Working Groups I, II and III to the Fifth Assessment Report of the Intergovernmental Panel on Climate Change. Geneva, IPCC, $151 \mathrm{p}$. 
Iverson, L. R., Schwartz, M. W., Prasad, A. M., 2004: How fast and far might tree species migrate in the eastern United States due to climate change? Global Ecology and Biogeography, 13:209-219.

Jermstad, K. D., Bassoni, D. L., Wheeler, N. C., Anekonda, T. S., Aitken, S. N., Adams, W. T. et al., 2001: Mapping of quantitative trait loci controlling adaptive traits in coastal Douglas-fir. II. Spring and fall cold-hardiness. Theoretical and Applied Genetics, 102:1152-1158.

Johnsen, Ø., Daehlen, O.G., Østreng, G., Skrøppa, T., 2005: Daylength and temperature during seed production interactively affect adaptive performance of Picea abies progenies. New Phytologist, 168:589596.

Kapeller, S., Lexer, M.J., Geburek, T., Hiebl, J., Schueler, S., 2012: Intraspecific variation in climate response of Norway spruce in the eastern Alpine range: selecting appropriate provenances for future climate. Forest Ecology and Management, 271:46-57.

Konnert, M., Fady, B., Gömöry, D., A’Hara, S., Wolter, F., Ducci, F. et al., 2015: Use and transfer of forest reproductive material in Europe in the context of climate change. European Forest Genetic Resources Programme (EUFORGEN). Rome, Bioversity International, $75+$ xvi $p$.

Kramer, K., Liesebach, M., Lorent, A., Ducousso, A., Gömöry, D., Hansen, J. et al., 2017: Chilling and forcing requirements for foliage bud burst of European beech (Fagus sylvatica L.) differ between provenances and are phenotypically plastic. Agricultural and Forest Meteorology, 234:172-184.

Kremer, A., Ronce, O., Robledo-Arnuncio, J. J., Guillaume, F., Bohrer, G., Nathan, R. et al., 2012: Longdistance gene flow and adaptation of forest trees to rapid climate change. Ecology Letters, 15:378-392.

Lefèvre, F., Boivin, T., Bontemps, A., Courbet, F., Davi, H., Durand-Gillmann, M. et al., 2014: Considering evolutionary processes in adaptive forestry. Annals of Forest Science, 71:723-739.

Lind, B. M., Menon, M., Bolte, C. E., Faske, T. M., Eckert, A. J., 2018: The genomics of local adaptation in trees: are we out of the woods yet? Tree Genetics and Genomes 14:art.29.

Lindgren, D., Paule, L., Shen, X.-H., Yazdani, R., Segerström, U., Wallin, J. E. et al., 1995: Can viable pollen carry scots pine genes over long distances? Grana 34:64-69.

Lindtke, D., Buerkle, C. A., Barbara, T., Heinze, B., Castiglione, S., Bartha, D. et al., 2012: Recombinant hybrids retain heterozygosity at many loci: new insights into the genomics of reproductive isolation in Populus. Molecular Ecology, 21:5042-5058.

Matthews, J. D., 1989: Sylvicultural Systems. Oxford, Clarendon Press, 284 p.
Mátyás, C., 1994: Modeling climate change effects with provenance test data. Tree Physiology, 14:797-804.

Mátyás, C., 1996: Climatic adaptation of trees: Rediscovering provenance tests. Euphytica, 92:45-54

Mátyás, C., 2007. What do feld trials tell about the future use of forest reproductive material? In: Koskela, J., Buck, A., Teissier du Cros, E. (eds.): Climate change and forest genetic diversity: Implications for sustainable forest management in Europe. Rome, Bioversity International, p. 53-69.

Messier, C., Bauhus, J., Doyon, F., Maure, F., SousaSilva, R., Noler, P. et al., 2019: The functional complex network approach to foster forest resilience to global changes. Forest Ecosystems, 6:art.21.

Montwe, D., Isaac-Renton, M., Hamann, A., Spiecker, H., 2018: Cold adaptation recorded in tree rings highlights risks associated with climate change and assisted migration. Nature Communications, 9:art.1574.

Neale, D. B., Kremer, A., 2011: Forest tree genomics: growing resources and applications. Nature Reviews Genetics, 12:111-122.

Nicotra, A. B., Atkin, O. K., Bonser, S. P., Davidson, A. M., Finnegan, E. J., Mathesius, U. et al., 2010: Plant phenotypic plasticity in a changing climate. Trends in Plant Science, 15:684-692.

O'Hara, K. L., 2016: What is close-to-nature silviculture in a changing world? Forestry 89:1-6.

Pigliucci, M., Murren, C. J., Schlichting, C. D., 2006: Phenotypic plasticity and evolution by genetic assimilation. Journal of Experimental Biology, 209:23622367.

Plomion, C., Bastien, C., Bogeat-Triboulot, M. B., Bouffier, L., Dejardin, A., Duplessis, S. et al., 2016: Forest tree genomics: 10 achievements from the past 10 years and future prospects. Annals of Forest Science, 73:77-103.

ProSilva, 2012: ProSilva principles. Available online at https://www.prosilva.org/fileadmin/prosilva/ 3_Close_to_Nature_Forestry/01_ProSilva_Principles/Pro_Silva_Principles_2012.pdf, accessed 10 April 2020.

Puettmann, K. J., Coates, D., Messier, C., 2009 A critique of silviculture. Managing for complexity. Washington, Island Press, $189 \mathrm{p}$.

Rehfeldt, G. E., Ying, C. C., Spittlehouse, D. L., Hamilton, D. A., 1999: Genetic responses to climate in Pinus contorta: niche breadth, climate change, and reforestation. Ecological Monographs, 69:375-407.

Ripple, W. J., Wolf, C., Newsome, T. M., Barnard, P., Moomaw, W. M., 2019: World scientists' warning of a climate emergency. BioScience, 70:8-12.

Savolainen, O., Pyhäjärvi, T., Knürr, T., 2007: Gene flow and local adaptation in trees. Annual Review of Ecology, Evolution and Systematics, 38:595-619. 
Schlichting, C. D., Smith, H., 2002: Phenotypic plasticity: linking molecular mechanisms with evolutionary outcomes. Evolutionary Ecology, 16:189-211.

Schütz, J.-P., Saniga, M., Diaci, J., Vrška, T., 2016: Comparing close-to-nature silviculture with processes in pristine forests: lessons from Central Europe. Annals of Forest Science, 73:911-921.

Silvestro, R., Rossi, S., Zhang, S. K., Froment, I., Huang, J. G., Saracino, A., 2019: From phenology to forest management: Ecotypes selection can avoid early or late frosts, but not both. Forest Ecology and Management, 436:21-26.

Skrøppa, T., 1994: Growth rhythm and hardiness of Picea abies progenies of high-altitude parents from seed produced at low elevations. Silvae Genetica, 43:95-100.

Skrøppa, T., Tollefsrud, M. M., Sperisen, C., Johnsen, O., 2009: Rapid change in adaptive performance from one generation to the next in Picea abies - Central European trees in a Nordic environment. Tree Genetics and Genomes, 6:93-99.

Smouse, P. E., Dyer, R. J., Westfall, R. D., Sork, V. L., 2001: Two-generation analysis of pollen flow across a landscape. I. Male gamete heterogeneity among females. Evolution, 55:260-271.

Spathelf, P., Bolte, A., van der Maaten, E., 2015: Is Closeto-Nature Silviculture (CNS) an adequate concept to adapt forests to climate change. Landbauforschung, 65:161-170.
Sthultz, C. M., Gehring, C. A., Whitham, T. G., 2009: Deadly combination of genes and drought: increased mortality of herbivore-resistant trees in a foundation species. Global Change Biology, 15:1949-1961.

St-Laurent, G. P., Hagerman, S., Kozak, R. 2018: What risks matter? Public views about assisted migration and other climate-adaptive reforestation strategies. Climatic Change, 151:573-587.

Valladares, F., Sanchez-Gomez, D., Zavala, M.A., 2006: Quantitative estimation of phenotypic plasticity: bridging the gap between the evolutionary concept and its ecological applications. Journal of Ecology, 94:1103-1116.

Williams, M. I., Dumroese, R. K., 2013: Preparing for climate change: forestry and assisted migration. Journal of Forestry, 111:287-297.

Woodall, C. W., Oswalt, C. M., Westfall, J. A., Perry, C. H., Nelson, M. D., Finley, A. O., 2009: An indicator of tree migration in forests of the eastern United States. Forest Ecology and Management, 257:1434-1444. Wortemann, R., Herbette, S., Barigah, T. S., Fumanal, B., Alia, R., Ducousso, A. et al., 2011: Genotypic variability and phenotypic plasticity of cavitation resistance in Fagus sylvatica L. across Europe. Tree Physiology, 31:1175-1182. 